\title{
ETHNOBIOLOGY STUDY ON NATURE AND PROCESSING PLANTS AND ANIMALS IN TRADITIONAL SEA-PICKING OF BANYUWANGI REGENCY
}

\author{
Sylvia Rimbanita Purwanto, Ika Lia Novenda*, Erlia Narulita \\ Program Studi Pendidikan IPA, FKIP Universitas Jember \\ Jalan Kalimantan No. 37, Jember 68121, Jawa Timur, Indonesia \\ *ikanovenda11@gmail.com
}

Doi: https://doi.org/10.31943/mangiferaedu.v5i1.90

Received: April 8, $2020 \quad$ Accepted: July 25, $2020 \quad$ Published: July 31, 2020

Citation: Purwanto, S. R., Novenda, I. L. \& Narulita, E. (2020). Ethnobiology Study on

Nature and Processing Plants and Animals in Traditional Sea-Picking of Banyuwangi Regency. Jurnal Mangifera Edu, 5(1), 38-54.

\begin{abstract}
The traditional sea-picking ceremony is a ritual carried out by the community as a form of gratitude for the abundance of sustenance provided by God, as well as for asking safety of fishermen. Besides aiming for blessings and safety, the traditional sea picking ceremony also has an important role as a means of communication for fishermen, and maintaining harmony among religious communities, therefore this traditional sea picking ceremony must be held once every year. The purpose of this study was to observe the nature and processing of plants and animals at sea picking ceremony and to find out the Use Value $(U V)$ of plants, animals and the natural environment used. Sampling of informants was done by Purposive Sampling and Snowball Sampling; data obtained using semistructured interviews with open ended question types. The results showed there were 66 species from 37 plant families and 3 species from two animal families. While the Use Value (UV) analysis indicate that there were 12 plant species and one animal species that have a high Use Value $(U V)$ which is 1 , it shows that the species is most widely used in traditional sea picking ceremonies. Generally, it needs more efforts for further conservation.
\end{abstract}

Keywords: Muncar, Ethnobiology, Traditional sea-picking ceremony, Pesanggaran.

\section{ABSTRAK}

Upacara adat petik laut merupakan sebuah ritual yang dilaksanakan oleh masyarakat Kabupaten Banyuwangi sebagai wujud syukur terhadap limpahan rezeki yang diberikan oleh Tuhan, dan untuk memohon keselamatan bagi para nelayan. Selain bertujuan untuk memohon berkah dan keselamatan, upacara adat petik laut juga memiliki peran penting sebagai sarana komunikasi bagi para nelayan, dan menjaga kerukunan antar umat beragama, oleh karena itu upacara adat petik laut ini wajib diadakan setiap satu kali dalam satu tahun. Tujuan dari penelitian ini adalah untuk mengetahui apa saja dan bagaimana cara pengolahan tumbuhan dan hewan pada upacara adat petik laut dan untuk mengetahui nilai Use Value (UV) dari tumbuhan, hewan dan lingkungan alam yang digunakan pada upacara adat petik laut. Pengambilan sampel narasumber dilakukan dengan Purposive Sampling dan Snowball Sampling, data diperoleh menggunakan wawancara semistructured dengan tipe pertanyaan open ended. Hasil penelitian menunjukkan terdapat 66 spesies dari 37 famili tumbuhan dan 3 spesies dari 2 famili 
hewan. Sedangkan hasil analisis Use Value (UV) menunjukkan terdapat 12 spesies tumbuhan dan 1 spesies hewan yang mendapatkan nilai Use Value (UV) sebesar 1, dimana hal tersebut menunjukkan bahwa spesies tersebut paling banyak digunakan pada upacara adat petik laut, sehingga mengasosiasikan akan adanya suatu upaya konservasi.

Kata Kunci: Muncar, etnobiologi, petik laut, Pesanggaran.

\section{PENDAHULUAN}

Indonesia merupakan wilayah kepulauan terbesar di dunia yang memiliki berbagai potensi diantaranya potensi sumber daya hayati, sumber daya mineral dan energi, industri dan jasa maritim, transportasi laut dan jasa lingkungan serta budaya atau kearifan lokal (Trinanda, 2017). Kearifan lokal merupakan segala bentuk keyakinan, pengetahuan, pemahaman, atau wawasan serta adat kebiasaan dan etika yang menuntun perilaku manusia dalam kehidupan komunitas ekologis (Pramita et al., 2013). Setiap daerah di Indonesia memiliki kearifan lokal khas yang tidak dimiliki oleh daerah lain. Berbagai macam kearifan lokal tertuang dalam nilai-nilai keseharian, sastra tutur, hukum adat, serta dalam bentuk upacara adat dan kepercayaan (Febriyanto \& Kumaini, 2019). Salah satu daerah di Indonesia yang memiliki kearifan lokal yang khas adalah Kabupaten Banyuwangi. Kabupaten Banyuwangi merupakan kabupaten terluas di daerah Jawa Timur dengan luas wilayah $5,782.50 \mathrm{~km}^{2}$, terdiri atas 25 Kecamatan, 28 Kelurahan dan 189 desa, 87 Lingkungan dan 751 Dusun, 2,839 Rukun Warga (RW) dan 10,569 Rukun Tetangga (RT) (Dinas Kependudukan dan Pencatatan Sipil Kabupaten Banyuwangi, 2019).

Kekhasan budaya Kabupaten Banyuwangi dapat dilihat pada pelaksanaan berbagai upacara adat yang ada di Banyuwangi, salah satunya upacara adat petik laut. Upacara adat petik laut merupakan ritual yang dilaksanakan oleh masyarakat sebagai wujud syukur terhadap limpahan rezeki yang diberi Tuhan, selain itu juga dimaksudkan untuk memohon keselamatan bagi para nelayan (Sawiji et al., 2017). Selain bertujuan untuk memohon berkah dan keselamatan, upacara adat petik laut juga memiliki peran penting sebagai sarana komunikasi bagi para nelayan, dan menjaga kerukunan antar umat beragama. Dengan diadakannya upacara adat petik laut, dapat menjadi ajang silaturahmi dan menjalin hubungan yang harmonis antar umat beragama, oleh karena itu upacara adat petik laut ini wajib diadakan setiap satu kali dalam satu tahun (Dewi et al., 2014).

Upacara adat petik laut di Banyuwangi tetap dijaga kelestariannya karena alasan lain pula yakni menjadi kegiatan pariwisata. Dengan adanya upacara adat petik laut ini diharapkan dapat menarik wisatawan baik dari daerah Banyuwangi sendiri maupun dari luar kota untuk ikut serta melihat kegiatan upacara adat petik laut. Daerah di Kabupaten 
Banyuwangi yang melaksanakan upacara adat petik laut antara lain di Kecamatan Banyuwangi, Kecamatan Muncar, dan Kecamatan Pesanggaran Banyuwangi.

Pada upacara adat petik laut terdapat kelengkapan sesaji yang digunakan berasal dari tumbuhan, hewan serta memanfaatkan lingkungan. Berdasarkan hasil survey sementara, diketahui bahan yang digunakan pada upacara adat petik laut antara lain kepala sapi (Bos taurus), kepala kambing (Capra aegagrus hircus), kelapa (Cocos nucifera), tebu hitam (Saccharum officinarum L.), berbagai macam buah-buahan, bunga mawar (Rosa sp.), melati (Jasminum), kantil (Magnolia alba), jagung (Zea mays), pinang (Areca catechu), beras putih (Oryza sativa) dan masih banyak bahan lain yang menggambarkan hubungan manusia yang tidak bisa terlepas dari alam.

Pada upacara adat petik laut di Kabupaten Banyuwangi terdapat beberapa tumbuhan yang sulit didapatkan. Akan tetapi tumbuhan tersebut harus tetap ada karena memiliki makna, filosofi dan peran tersendiri pada upacara adat petik laut. Salah satu contohnya adalah tumbuhan pinang (Areca catechu). Pinang (Areca catechu) merpupakan bagian dari sesajen yang digunakan pada upacara adat petik laut khususnya pada bagian bunganya. Pinang (Areca catechu) merupakan tumbuhan palma yang tingginya dapat mencapai 12- 30 meter, berakar serabut, batang tegak lurus, bergaris dan tidak memiliki cabang. Pohon pinang tumbuh di daerah Asia salah satunya di Indonesia. Pinang biasanya digunakan sebagai bahan ramuan, obat, upacara adat dan masyarakat tradisional biasanya menggunakan bijinya untuk dikunyah (nginang) (Staples \& Bevacqua, 2006).

Masyarakat sekitar pesisir pantai di Kabupaten Banyuwangi yang menyelenggarakan upacara adat petik laut mengaku kesulitan untuk mendapatkan tanaman pinang khususnya bagian bunganya. Menurunnya keanekaragaman hayati salah satunya pohon pinang ini disebabkan karena faktor utama yakni kecenderungan penggunaan tumbuhan untuk memenuhi kebutuhan masyarakat (Putri \& Allo, 2009). Permasalahan ini tentu membutuhkan adanya upaya konservasi yang memerlukan kesadaran dari masyarakat sehingga keanekaragaman hayati dapat terus terjaga dan dapat memenuhi kebutuhan masyarakat khususnya upacara adat petik laut.

Etnobiologi dapat diartikan secara umum sebagai evaluasi ilmiah terhadap pengetahuan penduduk tentang biologi, yang mencakup pengetahuan tentang tumbuhan, hewan dan lingkungan alam (Iskandar, 2017). Sejauh ini penelitian mengenai etnobiologi upacara adat petik laut oleh masyarakat Kabupaten Banyuwangi belum pernah dilakukan. Selain itu belum ada sumber yang dapat memberikan pengetahuan tentang pemanfaatan sumber daya alam oleh masyarakat Kabupaten Banyuwangi pada upacara adat petik laut, 
sehingga penting sekali untuk dilakukan kajian terhadap tumbuhan, hewan, dan lingkungan alam yang digunakan oleh masyarakat Kabupaten Banyuwangi, mengetahui cara pemanfaatan tumbuhan, hewan dan lingkungan alam serta nilai Use value (UV) tumbuhan, hewan dan lingkungan alam yang digunakan oleh masyarakat Kabupaten Banyuwangi pada upacara adat petik laut.

\section{METODOLOGI PENELITIAN}

Penelitian ini dilakukan pada wilayah Kabupaten Banyuwangi yaitu Kecamatan Banyuwangi, Kecamatan Muncar, dan Kecamatan Pesanggaran, khususnya Kelurahan Kampung Mandar, Desa Kedungrejo dan Desa Sumberagung. Penelitian dilaksanakan dua tahap yakni tahap observasi dan dokumentasi pada bulan September 2019, serta tahap wawancara pada bulan Januari- Februari 2020. Adapun jenis penelitian ini adalah penelitian deskriptif eksploratif dengan menggunakan gabungan metode penelitian kualitatif dan metode penelitian kuantitatif (Wagiran, 2019).

Teknik pengambilan sampel narasumber dengan menggunakan Purposive Sampling dan Snowball Sampling. Teknik pengumpulan data dilakukan dengan wawancara, observasi dan dokumantasi. Teknik wawancara dilakukan dengan sejumlah responden pada masingmasing wilayah. Teknik wawancara yang digunakan adalah wawancara semi-structured (semi terstruktur) dengan tipe pertanyaan open-ended (terbuka) (Edi, 2016). Tumbuhan dan hewan yang digunakan pada upacara adat akan diidentifikasi sesuai dengan ciri-cirinya dengan menggunakan buku panduan identifikasi. Selain itu pengidentifikasian tumbuhan dan hewan juga dilakukan dengan cara pencarian nama ilmiah di beberapa website terpercaya yaitu ITIS, Plantamor dan Eol serta dibantu oleh dosen dalam bidangnya.

Kepentingan relatif spesies tumbuhan yang digunakan pada etnobiologi upacara adat petik laut dihitung dengan menggunakan use value (UV) untuk masing-masing spesies (Bhattarai, 2018). Nilai UV didasarkan pada jumlah responden yang mengetahui atau menggunakan tumbuhan, hewan, dan lingkungan alam pada upacara adat petik laut. UV dapat menunjukkan spesies yang paling penting, sehingga mengasosiasikan akan adanya suatu upaya konservasi pada spesies tersebut. Spesies tumbuhan dengan nilai UV yang tinggi menunjukkan bahwa spesies tersebut paling banyak digunakan (Albuquerque et al., 2006). Use value (UV) dapat dihitung dengan rumus sebagai berikut: 


$$
U V=\frac{\sum \mathrm{U}}{n}
$$

Keterangan :

$\mathrm{UV}=$ Nilai Use Value

$\sum \mathrm{U}=$ Jumlah informan yang mengetahui atau menggunakan spesies tumbuhan.

$\mathrm{n} \quad=$ Jumlah keseluruhan informan

\section{HASIL DAN PEMBAHASAN}

Berdasarkan penelitian yang telah dilakukan, terdapat sebanyak 4 responden. 1 responden berasal dari Kelurahan Kampung Mandar, 1 responden berasal dari Desa Kedungrejo, dan 2 responden berasal dari Desa Sumberagung. Dari responden yang disebutkan, 3 diantaranya merupakan pemangku adat pada upacara adat petik laut. Khusus Desa Sumberagung terdapat 2 responden yakni pemangku adat dan dibantu oleh istrinya yang juga memiliki pengetahuan tentang upacara adat petik laut.

\section{Tumbuhan, Hewan dan Lingkungan Alam yang Digunakan oleh Masyarakat Kabupaten Banyuwangi pada Upacara Adat Petik Laut}

Berdasarkan penelitian yang telah dilakukan pada upacara adat petik laut diketiga kecamatan yakni Kecamatan Banyuwangi, Muncar dan Pesanggaran, terdapat sebanyak 66 spesies dari 37 famili tumbuhan, dan 3 spesies dari 2 famili hewan. Sedangkan untuk lingkungan alam yang digunakan pada upacara adat petik laut di ketiga kecamatan merupakan lingkungan sekitar pesisir pantai dan lautan. Upacara adat petik laut di Kelurahan Kampung Mandar, Kecamatan Banyuwangi memanfaatkan sebanyak 22 spesies tumbuhan dan 2 spesies hewan, upacara adat petik laut di Desa Kedungrejo, Kecamatan Muncar memanfaatkan sebanyak 45 spesies tumbuhan dan 2 spesies hewan, sedangkan upacara adat di Desa Sumberagung Kecamatan Pesanggaran memanfaatkan sebanyak 37 spesies tumbuhan dan 2 spesies hewan (Gambar 1). 


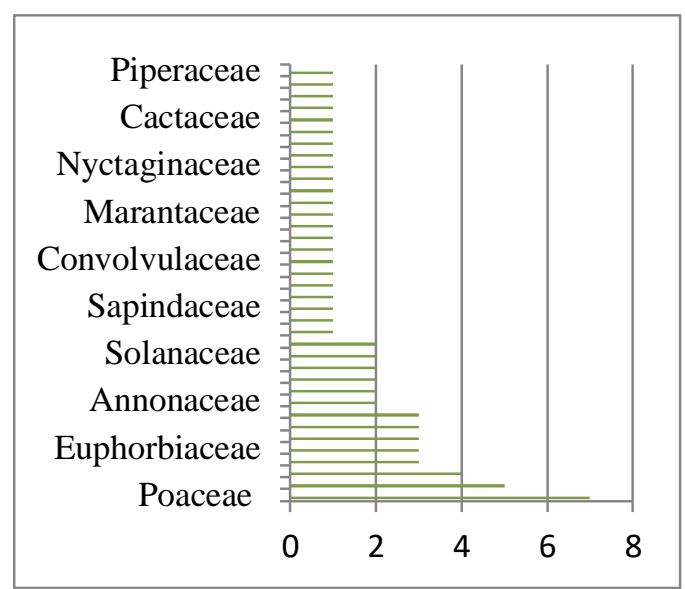

\section{Jumlah Spesies Tumbuhan}

\section{Gambar 1. Distribusi Jumlah Spesies Tumbuhan sebagai Bahan Upacara Adat Petik Laut di} Tiga Kecamatan di Kabupaten Banyuwangi

Masyarakat di Kabupaten Banyuwangi khususnya di tiga kecamatan yang menyelenggarakan upacara adat petik laut banyak menggunakan tumbuhan yang termasuk kedalam famili Poaceae (Gambar 1). Terdapat sebanyak 7 spesies yang termasuk famili Poaceae, contohnya beras putih (Oryza sativa), beras ketan (Oryza sativa var. glutinosa), beras ketan hitam (Oryza sativa L. Indica), dan beras merah (Oryza punctata Kotschy ex Steud) yang digunakan sebagai bahan pembuatan tumpeng dan jenang 5 warna. Famili Poaceae juga banyak digunakan pada upacara adat di sekitar Taman Nasional Bromo Tengger Semeru yakni sebanyak 11 spesies, contohnya bambu apus (Gigantochloa apus) yang digunakan sebagai tali untuk petra atau bespa ketika upacara adat entas-entas berlangsung dan beras putih (Oryza sativa) yang juga digunakan juga dalam pembuatan tumpeng dan jenang (Wijayanti, 2017).

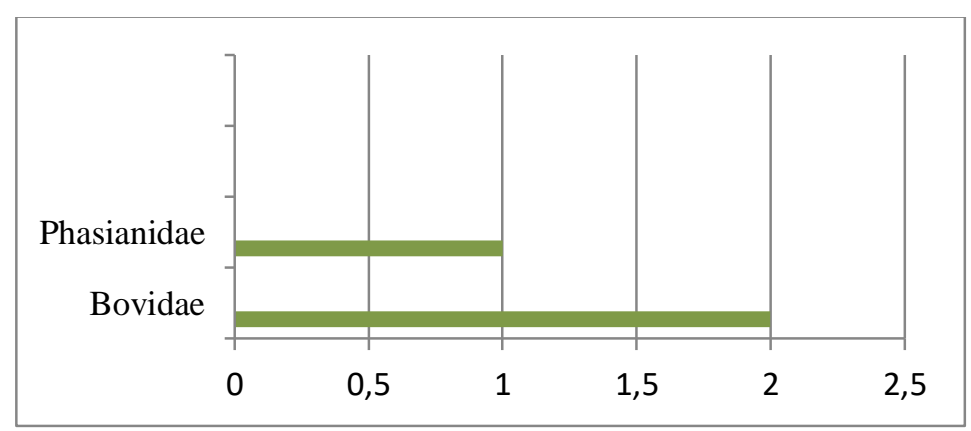

Jumlah Spesies Hewan

Gambar 2. Distribusi Jumlah Spesies Hewan sebagai Bahan Upacara Adat Petik Laut di Tiga Kecamatan di Kabupaten Banyuwangi

Hewan yang digunakan pada upacara adat petik laut di Kabupaten Banyuwangi ini masuk kedalam 2 famili dan 3 spesies, yang termasuk kedalam famili Bovidae adalah 
kambing (Capra aegagrus hircus), dan sapi (Bos taurus). Sedangkan hewan yang termasuk kedalam famili Phasianidae adalah ayam kampung (Gallus gallus domesticus).

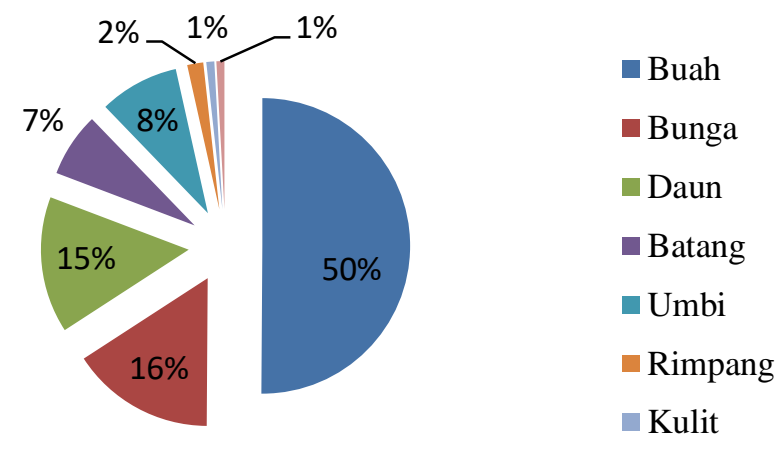

\section{Gambar 3. Organ Tumbuhan yang digunakan Oleh Masyarakat Kabupaten Banyuwangi sebagai Bahan Upacara Adat Petik Laut}

Berdasarkan Gambar 3, diketahui bahwa organ tumbuhan yang paling banyak digunakan adalah buah sebanyak 50\%, bunga sebanyak 16\%, dan daun sebanyak $15 \%$. Hal ini sejalan dengan penelitian yang dilakukan oleh Amrul \& Lubis (2017), bahwa organ tumbuhan yang banyak digunakan pada upacara adat adalah daun, bunga dan buah. Buah pada upacara adat petik laut di tiga kecamatan ini memang banyak digunakan. Buah yang digunakan seperti apel (Malus domestica), pir (Pyrus pyrifolia), anggur (Vitis vinifera L.), beras (Oryza sativa), nanas (Ananas cosmosus), salak (Salacca zalacca), sawo (Manilkara zapota), sawo duren (Chrysophyllum cainito) dan lain sebagainya. Buah pada upacara adat petik laut ini merupakan hasil bumi yang tersmasuk dalam komponen sesajen yang harus ada. Sedangkan bunga juga merupakan komponen dalam sesajen, diantaranya terdapat bunga mawar (Rosa sp), kantil (Michelia alba), melati (Jasminum), kenanga (Cananga odorata), dan bunga sedap malam (Polianthes tuberosa). Menurut Putri, et al., (2013), spesies yang digunakan pada upacara adat merupakan tumbuhan dengan bunga yang menarik. Bunga- bunga dengan warna yang berbeda memiliki makna tersendiri yatu makna kehidupan. Kemudian bagian daun tumbuhan juga banyak digunakan, seperti daun waru (Hibiscus tiliaceus). Pada upacara adat petik laut di Kampung Mandar, daun waru digunakan sebagai tatakan. Selain daun waru, masyarakat juga memanfaatkan daun kelapa muda. Daun kelapa (Cocos nucifera) yang masih muda banyak memiliki fungsi seperti digunakan sebagai pembungkus ketupat lepet dan bahan kembar mayang. Kembar mayang merupakan sebuah buket dari daun kelapa muda yang dibentuk dengan sedemikian rupa dan menggunakan tambahan beberapa jenis bunga dan daun seperti bunga pinang. Penggunaan bunga pinang 
ini melambangkan meminang/memulai kehidupan baru dan mengharapkan hajat yang diinginkan terkabul (Anggraini et al., 2018).

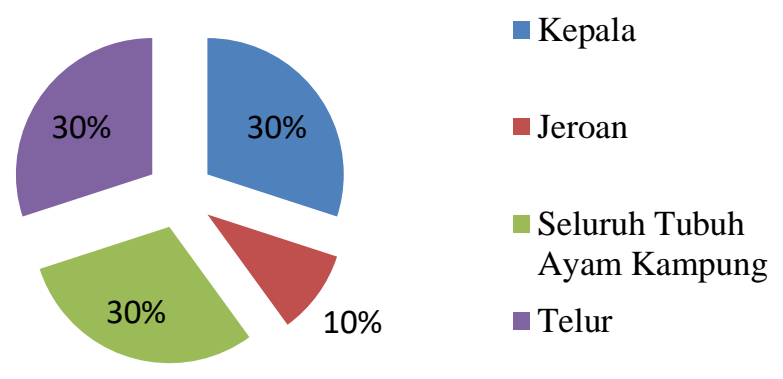

\section{Gambar 4. Organ Hewan yang Digunakan oleh Masyarakat Kabupaten Banyuwangi sebagai Bahan Upacara Adat Petik Laut}

Berdasarkan Gambar 4, dapat diketahui bahwa penggunaan organ kepala, seluruh tubuh ayam kampung, dan telur ayam kampung memiliki persentase yang sama. Hal tersebut dikarenakan masyarakat pada ketiga wilayah upacara adat petik laut di Kabupaten Banyuwangi menggunakan organ tersebut sebagai bahan pada upacara adat petik laut. Upacara adat petik laut di Kelurahan Kampung Mandar menggunakan kepala sapi, sedangkan di Desa Kedungrejo dan Desa Sumberagung menggunakan kepala kambing kendit. Upacara adat petik laut memang sudah diwariskan secarta turun temurun, dan salah satu sesajen yang sangat penting yakni penggunaan kepala sapi atau kambing kendit (Setiawan, 2016). Pemilihan kepala sapi atau kambing tersebut didasarkan atas apa yang diajarkan oleh nenek moyang terdahulu. Kepala sapi atau kambing yang digunakan tersebut memiliki makna sebagai persembahan.

Selanjutnya diketahui bahwa tanaman yang digunakan sebagai bahan upacara adat petik laut di tiga kecamatan diperoleh dengan cara budidaya, liar dan membeli. Sedangkan keseluruhan hewan yang digunakan didapat dari membeli seperti kepala sapi, kepala kambing kendit dan ayam kampung, masyarakat di Krajan Kampung Mandar, masyarakat Desa Kedungrejo, dan masyarakat Desa Sumberagung seluruhnya membeli bahan-bahan tersebut (Gambar 5). 


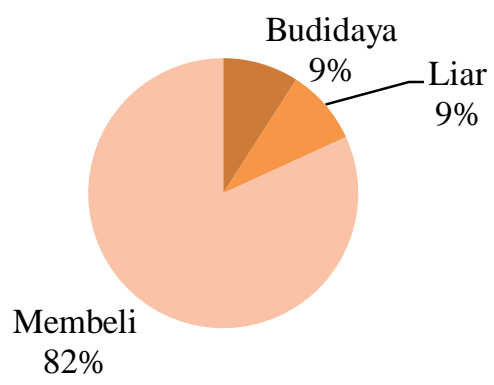

\section{Gambar 5. Asal Perolehan Tumbuhan sebagai Bahan pada Upacara Adat Petik Laut di Ketiga Kecamatan di Kabupaten Banyuwangi}

Berdasarkan Gambar 5, dapat diketahui tumbuhan yang diperoleh dari budidaya dan liar masing- masing sebesar 9\% sedangkan tumbuhan yang diperoleh dari proses membeli sebanyak $82 \%$. Tanaman yang dibudidaya kebanyakan dilakukan di Kelurahan Kampung Mandar, Kecamatan Banyuwangi, sedangkan kecamatan lain hanya beberapa yang melakukan budidaya, bahkan tumbuhan didapatkan dari tumbuhan liar. Hal ini mungkin terjadi karena kurangnya kepedulian masyarakat terhadap upaya konservasi tumbuhan atau kurangnya lahan/pekarangan yang digunakan untuk budidaya (Anggraini, et al., 2018). Budidaya beberapa tumbuhan dilakukan untuk mengantisipasi apabila terdapat tumbuhan yang sulit didapatkan, seperti contohnya pisang raja, bunga pinang dan tebu hitam.

Cara Pemanfaatan Tumbuhan, Hewan dan Lingkungan Alam oleh Masyarakat pada Upacara Adat Petik Laut di Kecamatan Banyuwangi, Kecamatan Muncar, dan Kecamatan Pesanggaran Kabupaten Banyuwangi

Upacara adat petik laut yang dilaksanakan diketiga kecamatan tersebut tentu terdapat beberapa perbedaan dalam cara mengolah dan memanfaatkan tumbuhan maupun hewan yang digunakan. Pengolahan sesajen mulai dari menyiapkan, mencuci, memasak, memotong dan mengolah lebih lanjut tumbuhan atau hewan untuk upacara adat petik laut relatif sama, perbedaannya pada hasil peracikannya atau dalam menata dan banyaknya tumbuhan dan hewan yang digunakan. Cara pengolahan tumbuhan dan hewan yang digunakan sebagai sesajen pada upacara adat tersebut diperoleh secara turun- temurun atau berdasarkan pengetahuan dan pengalaman orang lain (Purwanti, et al., 2017).

Upacara adat petik laut di Kelurahan Kampung Mandar memiliki pemanfaatan tumbuhan yang lebih sedikit daripada pemanfaatan tumbuhan pada upacara adat petik laut di kecamatan lain. Pada upacara adat petik laut di Kampung Mandar tidak menggunakan terlalu banyak hasil bumi, akan tetapi terdapat beberapa olahan tumbuhan dan juga hewan yang digunakan pada upacara adat petik laut di Kampung Mandar. Seperti olahan paling khas dan harus ada pada upacara adat petik laut di Kampung Mandar yakni minyak Mandar. 
Minyak Mandar merupakan minyak yang berwarna merah yang terbuat dari kelapa dan campuran lain dan mantra atau doa yang hanya diketahui oleh pemangku adat.

Olahan lain yang digunakan pada upacara adat petik laut di kampung Mandar ini yakni ada tumpeng kecil berjumlah 5 buah. Tumpeng kecil ini terbuat dari beras yang telah dimasak dan diberi 5 warna berbeda, yakni ada warna merah, putih, hijau, hitam dan kuning kemudian dibentuk kerucut kecil. Tumpeng kecil ini disusun diatas wadah tampah plastik yang sudah diberi taburan bunga mawar. Tumbuhan yang digunakan kebanyakan disusun pada wadah-wadah plastik yang telah diberi alas daun waru, didalamnya terdapat pisang raja yang di tusuk dengan dua buah colok, disusun bersama bunga mawar (Rosa sp.), kenanga (Cananga odorata), bunga sedap malam (Polianthes tuberosa), kelapa gading (Cocos nucifera), tebu hitam (Saccharum officinarum L.), rokok kelobot, daun sirih (Piper betle), beras kuning, telur ayam yang telah dibalur dengan minyak mandar, dan tumpeng kecil. Selanjutnya juga ada yang dinamakan peras, peras ini merupakan bagian dari sesajen. Peras merupakan bahan-bahan yang dikumpulkan dalam satu wadah yang isinya terdapat beras, kelapa, pisang saba, sirih, dan kopi.

Sesajen utama yang digunakan adalah kepala sapi. Kepala sapi (Bos taurus) yang digunakan haruslah kepala dari sapi jantan yang sehat. Kepala sapi yang telah digunakan dimandikan dan dicuci hingga bersih. Setelah bersih kepala sapi tersebut dibedaki dengan bedak tepung tawar dan diberi cilak pada bagian bawah matanya. Setelah itu diberi minum arak agar tidak menimbulkan bau yang menyengat saat didiamkan semalaman. Kepala sapi ini selanjutnya dibungkus dengan kain putih, dipasangkan emas pada bagian hidungnya dan pada bagian dahinya dipasangkan rangkaian bunga mawar (Rosa sp.), kenanga (Cananga odorata), bunga sedap malam (Polianthes tuberosa) dan kantil (Michelia alba). Selain bagian kepala sapi, ada juga bagian dari tubuh sapi yang digunakan yakni bagian jeroan seperti hati, jantung, paru-paru, darah dan sedikit bagian dari daging, yang diambil beberapa dan diletakkan pada daun waru yang telah dibentuk menjadi wadah. Hewan lain yang digunakan adalah ayam kampung (Gallus gallus domesticus). Ayam kampung yang digunakan ini dibiarkan hidup begitu saja sampai saat pelaksanaan upacara adat petik laut ayam kampung nantinya hanya akan dicelupkan ke air laut lalu di bawa kembali oleh pemangku adat.

Upacara adat petik laut di Desa Kedungrejo, Kecamatan Muncar menggunakan banyak hasil bumi yakni buah-buahan yang sangat melimpah seperti apel (Malus domestica), semangka (Citrullus lanatus), melon (Cucumis melo), nanas (Ananas cosmosus), jambu biji (Psidium guajava L.), buah naga (Hylocereus undatus), salak (Salacca zalacca), anggur 
(Vitis vinifera), pir (Pyrus pyrifolia), durian (Durio zibethinus), rambutan (Nephelium lappaceum), pala pendem yang telah direbus dan lain sebagainya. Pada upacara adat di Desa Kedungrejo ini, ada juga beberapa olahan tumbuhan seperti olahan beras (Oryza sativa) yang dijadikan jenang merah dan jenang putih. Selain itu ada juga olahan bernama ponar yang terbuat dari beras ketan putih (Oryza sativa var. glutinosa) yang dimasak bersama kunyit (Curcuma longa) sehingga berwarna kuning dan pada bagian atasnya diberi taburan kelapa parut yang telah dicampur dengan gula merah. Pada upacara adat petik laut di Desa Kedungrejo ini banyak juga menggunakan jajan pasar seperti hawuk- hawuk, kemplang (olahan ketan, kelapa dan gula pasir), kerupuk, mentari, nagasari yang diolah dari tepung beras dan pisang, serta ketupat yang terbuat dari beras putih. Ada pula olahan nasi, kulupan (sayur-sayuran) dan ingkung ayam kampung. Selanjutnya hewan yang digunkaan sebagai sesajen adalah kepala kambing kendit (Capra aegagrus hircus) dan ayam kampung (Gallus gallus domesticus). Kepala kambing dibungkus dengan kain putih dan diberi pancing emas pada bagian mulutnya. Sedangkan untuk ayam kampung dibiarkan hidup-hidup dan dimanfaatkan telurnya untuk sesajen.

Selanjutnya untuk upacara adat petik laut di Desa Sumberagung, Kecamatan Pesanggaran juga memanfaatkan banyak spesies tumbuhan. Seperti buah-buahan, pala pendhem, dan berbagai macam bunga-bungaan. Pada upacara adat petik laut yang diselenggarakan di Desa Sumberagung, beras putih (Oryza sativa), beras ketan (Oryza sativa var. glutinosa) dan kunyit (Curcuma longa) dimasak hingga matang dan dibentuk menjadi nasi tumpeng atau masyarakat menyebutnya sebagai ambeng jejeg yang bentuknya sangat besar. Pada bagian sekeliling ambeng jejeg diberi 7 macam buah-buahan seperti apel (Malus domestica), jeruk (Citrus), salak (Salacca zalacca), belimbing (Averrhoa carambola L.) dan jambu air (Syzygium aqueum), sedangkan pada bagian atasnya diberi satu buah nanas (Ananas cosmosus). Olahan tumbuhan lainnya dapat dilihat pada jenang sengkolo, ambengan, ketupat, dan lepet. Jenang sengkolo merupakan jenang yang terdiri atas 5 warna. Berbeda dengan masyarakat Krajan Kampung Mandar, jenang yang dibuat oleh Masyarakat Desa Sumberagung ini terbuat dari bahan yang berbeda pada setiap warnanya. Jenang yang berwarna merah terbuat dari beras merah (Oryza punctata Kotschy ex Steud), warna kuning terbuat dari jagung (Zea mays), warna hijau terbuat dari kacang hijau (Vigna radiate), warna hitam terbuat dari beras ketan hitam (Oryza sativa L. Indica), dan warna putih terbuat dari beras putih (Oryza sativa). Keseluruhan beras tersebut diolah dimasak dan dibentuk menjadi kerucut kecil. Kemudian ada ambengan yang merupakan nasi dan pada bagian atasnya diberi ingkung ayam kampung yang telah diolah. Selanjutnya ketupat merupakan olahan nasi dan 
lepet merupakan ketan putih ditambah kelapa parut yang di balut dengan daun kelapa yang masih muda.

Sama seperti yang dilakukan oleh masyarakat Muncar, masyarakat Desa Sumberagung Kecamatan Pesanggaran juga menggunakan kepala kambing kendit sebagai sesajen utama. Kepala kambing (Capra aegagrus hircus) yang sudah dibersihkan dibungkus kain putih. Pada keesokan harinya kepala kambing tersebut dipasangkan anting dan pancing emas oleh Bupati Banyuwangi. Selain kambing, ayam kampung (Gallus gallus domesticus) yang masih hidup juga digunakan sebagai sesajen. Ayam kampung yang digunakan juga ikut dilarungkan ke lautan. Ayam kampung hidup ini digunakan sebagai persembahan juga pertanda apakah sesajen yang dilarung diterima atau tidak. Apabila sesajen yang digunakan diterima maka ayam hidup yang dilarungkan tidak akan kembali ke daratan, dan apabila ayam kampung yang dilarungkan kembali ke daratan artinya sesajen tidak diterima karena diperkirakan mungkin terdapat sesajen yang kurang, sehingga perlu dilakukan petik laut kembali (Ainiyah, 2017).

Tumbuhan yang digunakan pada upacara adat petik laut oleh masyarakat Banyuwangi ini sebagian besar merupakan tumbuhan yang dapat tumbuh di sekitar tempat tinggal mereka, akan tetapi juga banyak tumbuhan yang didapatkan dari proses membeli. Tumbuhan yang digunakan sebagai sesajen kebanyakan menggunakan bagian buah, bunga dan daun. Sehingga untuk mendapatkan bagian-bagian tersebut dari suatu tumbuhan, dirasa masih mudah karena tidak mengambil satu bagian penuh dari suatu tumbuhan melainkan hanya buah, bunga atau daunnya saja. Hal tersebut tentu saja merupakan upaya yang sangat baik yang dilakukan oleh masyarakat dalam segi konservasi, karena pengambilan organorgan tersebut tidak terlalu berdampak pada suatu tumbuhan.

\section{Nilai Use Value (UV) Tumbuhan, Hewan dan Lingkungan Alam yang digunakan oleh Masyarakat Kabupaten Banyuwangi pada Upacara Adat Petik Laut.}

Hasil perhitungan nilai Use Value (UV) tumbuhan, hewan dan lingkungan alam yang paling banyak digunakan pada upacara adat petik laut dapat dilihat pada Tabel 1, 2 dan 3 berikut ini. 
Tabel 1. Nilai Use Value (UV) Lingkungan Alam yang digunakan pada Upacara Adat Petik Laut

$\begin{array}{cccc}\text { No. } & \text { Ekologi yang digunakan pada } & \text { Lokasi Upacara Adat } & \text { Nilai Use } \\ \text { Upacara Adat Petik Laut } & \text { (Pantai) } & \text { Value (UV) }\end{array}$

1. Pantai/ lautan

Pantai Boom, Pantai Muncar,

Pantai Pancer

Tabel 2. Nilai Use Value (UV) Tumbuhan yang digunakan pada Upacara Adat Petik Laut

\begin{tabular}{cllllc}
\hline No. & $\begin{array}{c}\text { Lokal (Jawa/ } \\
\text { Osing/ Madura) }\end{array}$ & \multicolumn{1}{c}{ Indonesia } & \multicolumn{1}{c}{ Ilmiah } & \multicolumn{1}{c}{$\begin{array}{c}\text { Lokasi Upacara } \\
\text { Adat } \\
\text { (Pantai) }\end{array}$} & $\begin{array}{c}\text { Nilai } \\
\text { Use } \\
\text { Value } \\
\text { (UV) }\end{array}$ \\
\hline 1. & Beras putih & Beras putih & Oryza sativa & $\begin{array}{l}\text { Boom, Muncar, } \\
\text { Pancer }\end{array}$ & 1 \\
\hline 2. & Daun mas-masan & Puring & $\begin{array}{l}\text { Codiaeum } \\
\text { variegatum }\end{array}$ & $\begin{array}{l}\text { Boom, Muncar, } \\
\text { Pancer }\end{array}$ & 1 \\
\hline 3. & Gedhang rojo & Pisang raja & $\begin{array}{l}\text { Musa x paradisiaca } \\
\text { L. }\end{array}$ & $\begin{array}{l}\text { Boom, Muncar, } \\
\text { Pancer }\end{array}$ & 1 \\
\hline 4. & Jagung & Jagung & Zea mays L. & $\begin{array}{l}\text { Boom, Muncar, } \\
\text { Pancer }\end{array}$ & 1 \\
\hline 5. & Kanthil & Kantil & Michelia alba & $\begin{array}{l}\text { Boom, Muncar, } \\
\text { Pancer }\end{array}$ & 1 \\
\hline 6. & Kenongo & Kenanga & Cananga odorata & $\begin{array}{l}\text { Boom, Muncar, } \\
\text { Pancer }\end{array}$ & 1 \\
\hline 7. & Klopo & Kelapa & Cocos nucifera & $\begin{array}{l}\text { Boom, Muncar, } \\
\text { Pancer }\end{array}$ & 1 \\
\hline 8. & Klopo gading & Kelapa gading & Cocos nucifera & $\begin{array}{l}\text { Boom, Muncar, } \\
\text { Pancer }\end{array}$ & 1 \\
\hline 9. & Kunir & Kunyit & Curcuma longa & $\begin{array}{l}\text { Boom, Muncar, } \\
\text { Pancer }\end{array}$ & 1 \\
\hline 10. & Mawar & Mawar & Rosa sp. & $\begin{array}{l}\text { Boom, Muncar, } \\
\text { Pancer }\end{array}$ & 1 \\
\hline 11. & Pinang & Pinang & Areca catechu & $\begin{array}{l}\text { Boom, Muncar, } \\
\text { Pancer }\end{array}$ & 1 \\
\hline 12. & Tebu ireng & Tebu hitam & $\begin{array}{l}\text { Saccharum } \\
\text { officinarum L. }\end{array}$ & $\begin{array}{l}\text { Boom, Muncar, } \\
\text { Pancer }\end{array}$ & 1 \\
\hline & & & & & 1 \\
\hline
\end{tabular}

Tabel 2. Nilai Use Value (UV) Hewan yang Digunakan pada Upacara Adat Petik Laut

\begin{tabular}{|c|c|c|c|c|c|}
\hline \multirow[b]{2}{*}{ No. } & \multicolumn{3}{|c|}{ Nama Hewan } & \multirow{2}{*}{$\begin{array}{c}\text { Lokasi Upacara } \\
\text { Adat } \\
\text { (Pantai) }\end{array}$} & \multirow{2}{*}{$\begin{array}{c}\text { Nilai } \\
\text { Use } \\
\text { Value } \\
\text { (UV) }\end{array}$} \\
\hline & $\begin{array}{c}\text { Lokal (Jawa/ } \\
\text { Osing/ Madura) }\end{array}$ & Indonesia & Ilmiah & & \\
\hline 1. & Ayam Kampung & $\begin{array}{l}\text { Ayam } \\
\text { Kampung }\end{array}$ & $\begin{array}{l}\text { Gallus gallus } \\
\text { domesticus }\end{array}$ & $\begin{array}{l}\text { Boom, Muncar, } \\
\text { Pancer }\end{array}$ & 1 \\
\hline 2. & Sapi & Sapi & Bos Taurus & Boom & 0,25 \\
\hline 3. & Wedhus & Kambing & $\begin{array}{l}\text { Capra aegagrus } \\
\text { hircus }\end{array}$ & $\begin{array}{l}\text { Boom, Muncar, } \\
\text { Pancer }\end{array}$ & 0,75 \\
\hline
\end{tabular}


Berdasarkan analisis Use Value (UV), lingkungan alam berupa lautan yang digunakan oleh masyarakat Kabupaten Banyuwangi pada upacara petik laut memiliki nilai Use Value (UV) sebesar 1. Dimana artinya lingkungan lautan berperan sangat penting dalam upacara adat petik laut ini. Upacara adat petik laut sudah pasti dilakukan oleh masyarakat untuk melarungkan sesajen ke tengah lautan, bukan di daratan. Hal tersebut mengingat tujuan dari upacara adat petik laut yakni merupakan perwujudan syukur terhadap limpahan rezeki yang diperoleh masyarakat nelayan, memohon keselamatan, dan berharap setelah dilakukan upacara adat petik laut rezeki yang didapatkan dari hasil laut semakin melimpah. Selanjutnya tumbuhan yang digunakan pada upacara adat petik laut yang memiliki nilai Use Value (UV) sebesar 1 didapatkan sebanyak 12 spesies, yakni beras putih (Oryza sativa), puring (Codiaeum variegatum), pisang raja (Musa x paradisiaca L.), jagung (Zea mays L.), kantil (Michelia alba), kenanga (Cananga odorata), kelapa (Cocos nucifera), kelapa gading (Cocos nucifera), kunyit (Curcuma longa), mawar (Rosa sp.), pinang (Areca catechu), dan tebu hitam (Saccharum officinarum L.). Sedangkan untuk hewan yang memiliki nilai Use Value (UV) sebesar 1 hanya ayam kampung (Gallus gallus domesticus). Hal tersebut menunjukkan bahwa tumbuhan dan hewan yang digunakan memiliki peran yang sangat penting dan harus ada dalam upacara adat petik laut di ketiga kecamatan di Kabupaten Banyuwangi.

Beras putih (Oryza sativa) banyak digunakan sebagai bagian dari kelengkapan sesajen sepert nasi ambeng jejeg, ambengan, ketupat, jenang putih, jenang merah, jenang sengkolo, dan beras kuning yang diberi pewarna kunyit untuk ditaburkan saat pelaksanaan upacara adat petik laut. Puring (Codiaeum variegatum) termasuk dalam bagian bunga setaman yang digunakan dalam sesajen, pisang raja (Musa x paradisiaca L.) digunakan sebagai sesajen, pisang termasuk perwujudan hasil bumi, jagung (Zea mays L.) pada upacara adat di Kampung Mandar hanya digunakan kulit buahnya saja untuk membuat rokok kelobot, sedangkan di kedua upacara adat petik laut lainnya digunakan sebagai perwujudan hasil bumi. Bunga kantil (Michelia alba), mawar (Rosa sp.), dan kenanga (Cananga odorata) termasuk kedalam sesajen bunga-bungaan, pada upacara adat petik laut di Desa Sumberagung, kantil, mawar, dan kenanga termasuk kedalam kembang 7 warna. Kunyit (Curcuma longa) banyak digunakan sebagai bahan pewarna. Kelapa (Cocos nucifera) dan kelapa gading (Cocos nucifera) memiliki makna harapan, cikal bakal suatu keinginan manusia yang dapat diwijudkan. Pinang (Areca catechu) digunakan bagian bunganya saja dan tebu hitam (Saccharum officinarum L). 
Hewan yang memiliki nilai guna yang tinggi adalah ayam kampung. Ayam kampung yang digunakan merupakan ayam kampung jantan yang sehat. Ayam kampung ini digunakan dalam 2 bentuk, yang pertama digunakan sebagai ingkung pada upacara adat petik laut di Muncar dan Pesanggaran. Kedua, ayam kampung dibiarkan hidup, terdapat perbedaan cara memperlakukan ayam kampung yang masih hidup pada ketiga kecamatan, pada masyarakat Kampung Mandar Kecamatan Banyuwangi, ayam kampung ini dibiarkan hidup-hidup untuk di celupkan ke air laut lalu kembali dibawa oleh pemangku adat. Sedangkan di Kecamatan Muncar dan Kecamatan Pesanggaran ayam kampung hidup ikut dilarungkan bersama sesajen lainnya.

Tumbuhan yang digunakan sebagai sesajen pada upacara adat petik laut di Kabupaten Banyuwangi ini diperoleh 9\% dari budidaya, 9\% tanaman liar dan sisanya $82 \%$ diperoleh dari membeli. Sedangkan berdasarkan analisis Use Value (UV) tumbuhan, setidaknya terdapat sebanyak 12 tumbuhan yang memiliki nilai guna yang tinggi. 12 spesies tersebut memiliki nilai yang lebih tinggi dari tumbuhan lainnya karena tumbuhan tersebut memiliki intensitas penggunaan yang tinggi, menjadi komponen utama yang berperan sangat penting dan tidak tergantikan oleh spesies lain (Anggraini, et al., 2018). Salah satu contohnya beras putih (Oryza sativa) yang merupakan bahan pokok pada upacara adat petik laut. Sementara itu persentase perolehan tumbuhan yang digunakan oleh masyarakat pada upacara adat petik laut menunjukkan upaya konservasi tumbuhan oleh masyarakat di tiga kecamatan di Kabupaten Banyuwangi yang melaksanakan upacara adat petik laut masih sangat rendah. Sedangkan upacara adat petik laut harus tetap dilakukan setiap tahun dan selalu memanfaatkan tumbuhan dalam pelaksanaannya, maka kegiatan konservasi perlu terus dilakukan untuk menghindarkan tumbuhan dari risiko kepunahan terlebih pada spesies yang memiliki nilai guna lebih tinggi daripada tumbuhan lain. Dalam hal ini pekarangan rumah bisa menjadi solusi dalam upaya konservasi tumbuhan (Putri, et al., 2013).

\section{SIMPULAN}

Masyarakat Kabupaten Banyuwangi memanfaatkan ekologi laut serta bermacammacam tumbuhan dan hewan pada pelaksanaan upacara adat petik laut. Tumbuhan yang digunakan sebagai bahan sesajen pada upacara adat petik laut sebanyak 66 spesies dari 37 famili tumbuhan dan 3 spesies dari 2 famili hewan. Tumbuhan yang paling banyak digunakan berasal dari famili Poaceae sedangkan hewan yang banyak digunakan berasal dari famili Bovidae. Organ tumbuhan yang paling banyak digunakan pada upacara adat petik laut adalah buah sebanyak 50\%, sedangkan organ hewan yang paling banyak digunakan adalah 
kepala, seluruh bagian tubuh ayam dan telur dimana masing-masing sebesar $30 \%$. Berdasarkan analisis Use Value (UV), terdapat 12 spesies tumbuhan dan 1 spesies hewan yang memiliki nilai guna tinggi yang mengasosiasikan bahwa perlu adanya upaya konservasi lebih lanjut oleh masyarakat agar keberadaan spesies tersebut tetap terjaga sehingga tetap dapat dimanfaatkan untuk upacara adat petik laut. Penelitian selanjutnya dianjurkan untuk meneliti mengenai upaya konservasi dan persepsi konservasi oleh masyarakat adat Kabupaten Banyuwangi, serta metode yang digunakan masyarakat Kabupaten Banyuwangi dalam melakukan konservasi.

\section{DAFTAR PUSTAKA}

Ainiyah, N. (2017). Ritual Petik Laut dan Keragaman (Keragaman dan Komunikasi Ritual di Kalangan Nelayan Multietnis di Kedungrejo Muncar Banyuwangi). Empirisma, 26(1), 69-84.

Alberqueque, U. P., Reinaldo, F. L. P., Julio, M. M., Alissandra, T. N. F \& Cecilia F. C. B. R. A. (2006). Evaluating Two Quantitative Ethnobotanical Techniques. Ethnobotany Research and Aplications, 4. 051-060.

Amrul, H. M. Z. N., \& Lubis, N. (2017). Etnobiologi Tumbuhan yang Dilakukan pada Upacara Sipaha Lima Masyarakat Parmalim. Prosiding SNaPP2017Sains dan Teknologi, pISSN 2089-3582.

Anggraini, T., Utami, S., \& Murningsih. (2018). Kajian Etnobotani Tumbuhan yang Digunakan pada Upacara Adat Pernikahan Adat Jawa di Sekitar Keraton Kasunanan Surakarta Hadiningrat. Jurnal Biologi, 7(3), 13-20.

Bhattarai, K. R. (2018). Ethnobotanical Study of Plants used by Thami Community in Ilam District, eastern Nepal. Our Nature, 16(1), 55-67.

Dewi, I. A. K. S., Sendratari, L. P., \& Mudana, I. W. (2014). Pemertahanan Tradisi Budaya Petik Laut oleh Nelayan Hindu dan Islam di Desa Pekutatan, Jembrana-Bali. Widya Winayata: Jurnal Pendidikan Sejarah, 2(1).

Dinas Kependudukan dan Pencatatan Sipil Kabupaten Banyuwangi. (2019). Banyuwangi: Dinas Kependudukan dan Pencatatan Sipil Kabupaten Banyuwangi.

Edi, F. R. S. (2016). Teori Wawancara Psikodiagnostik. Yogyakarta: PT. Leutika Novalitera.

Febriyanto, H., \& Kumaini, R. (2018). Ensiklopedia Keanekaragaman Tanaman Bahan Upacara Adat Masyarakat Kabupaten Banyuwangi (Kajian Etnobotani Dan Filosofis). Seminar Nasional Penelitian dan Pengabdian Masyarakat. LP4MP Universitas Islam Majapahit, 196- 206. 
Jurnal Mangifera Edu, Volume 5, Nomor 1, Juli 2020, 38-54

Iskandar, J. (2016). Etnobiologi dan Keragaman Budaya di Indonesia. Indonesian Journal of Anthropology, 1(1), eISSN 2528-1569.

Purwanti., Miswan., \& Pitopang, R. (2017). Studi Etnobotani Pada Proses Ritual Adat Masyarakat Suku Saluan di Desa Pasokan Kabupaten Tojo Una-Una. Biocelebes, 11(1), ISSN-p: 1978-6417.

Putri, I. A. S. L. P., \& Allo, M. K. (2009). Degradasi Keanekaragaman Hayati Taman Nasional Rawa Aopa Watumohai (Biodiversity Degradation of Rawa Aopa Watumohai National Park). Jurnal Penelitian Hutan dan Konservasi Alam, 6(2), 169194.

Putri, R. I., Supriatna, J., \& Walujo, E. B. (2013). Etnobotani Tumbuhan Penunjang Ritual Adat di Pulau Serangan Bali. Prosiding Seminar Nasional Prodi Biologi, ISBN: 978602-9138-68-9.

Pramita, N.H., Indriyani, S., \& Hakim, L. (2013). Etnobotani Upacara Kasada Masyarakat Tengger, di Desa Ngadas, Kecamatan Poncokusumo, Kabupaten Malang. Journal of Indonesia Tourism and Development Studies, 1(2), 52- 61.

Sawiji, A., Mauludiyah, M., \& Munir, M. 2017. Petik Laut Dalam Tinjauan Sains dan Islam. Jurnal Teknik Lingkungan, 2(2), 68-74.

Setiawan, E. (2016). Eksistensi Budaya Bahari Tradisi Petik Laut di Muncar Banyuwangi. Universum, 10(2), 229-237.

Staples, G. W., \& Bevacqua, R. F. (2006). Areca catechu (betel nut palm). Species Prpfiles for Pacific Island Agroforestry. traditionaltree.org (online).

Trinanda, T. C. (2017). Pengelolaan Wilayah Pesisir Indonesia dalam Rangka Pembangunan Berbasis Kelestarian Lingkungan. Jurnal Matra Pembaruan, 1(2), 75-84.

Wagiran. 2019. Metodologi Penelitian Pendidikan (Teori dan Implementasi). Yogyakarta: Deepublish Publisher.

Wijayanti, R. E. (2017). Etnobotani Upacara Adat di Sekitar Taman Nasional Bromo Tengger Semeru dan Pemanfaatannya sebagai Buku Ilmiah Populer. Skripsi. Jember: Universitas Jember. 